World Lumen Congress 2021 | May 26-30, 2021 |

Iasi, Romania

\title{
Considerations on the Infringement Procedure against Romania
}

\author{
Crina Mihaela VERGA
}

https://doi.org/10.18662/wlc2021/71

How to cite: Verga, C. M. (2021). Considerations on the Infringement Procedure against Romania. In A. Sandu (vol. ed.), Lumen Proceedings: Vol. 17 World Lumen Congress 2021 (pp. 706-713). Iasi, Romania: LUMEN Publishing House. https://doi.org/10.18662/wlc2021/71 


\title{
Considerations on the Infringement Procedure against Romania
}

\author{
Crina Mihaela VERGA ${ }^{1}$
}

\begin{abstract}
This paper is a study of the infringement procedure, as it is regulated at EU level. Thus, we first analyze the existing legal framework on the matter. The implementation of this procedure in various Member States of the European Union and its consequences are then presented. Last but not least, the article refers to a series of aspects regarding the fields in which the procedure was directed against Romania since its integration into the EU.

The purpose of the essay is to present in detail Romania's situation regarding the violation of EU's law. Thus, a comparative presentation throughout time of the number of such proceedings launched against the Romanian state was made. A relevant case in which Romania was tried and convicted was also presented in detail.The large number of cases launched in 2021 bighlights the delays registered by Romania on the matter.

The measures ordered by the Romanian government through the elaborated the Annual Transposition Plan2021 must be carefully and systematically implemented. Romania could also consider and effectively apply the examples of good practice from the other EU's member states.

The historical and the comparative methods used in this presentation reveal both the similarities between the application of this procedure in the EU Member States under review as well as the differences and its succession in time.

The article is important not only for the scientists, but also for the practitioners to dispose all the necessary measures that are required.
\end{abstract}

Keywords: Infringement, European Union, the states' practice, Romania.

\section{Introduction}

The notion of infringement is a procedure initiated as a result of a breach of primary and secondary legislation adopted at European Union level. Its purpose is to harmonize the legislation of each Member State with the system of European Union law, giving Member States the opportunity to resolve a particular issue determined by the European Commission before it reaches the Court of Justice.

\footnotetext{
${ }^{1}$ Lecturer Ph.D., "George Bacovia" University of Bacau, "Al.I.Cuza" University of Iasi, Romania, crinaverga2000@yahoo.com, 0040740292978.
} 
This mechanism represents an amicable settlement of a situation that would lead to the initiation of the procedure in question.

\section{The relevant legal framework and the specific procedure}

The legal basis of this procedure can be found in Articles 106, 258, 259 and 260 of the Treaty on the Functioning of the EU and it highlights a number of specific steps that are required to be followed.

In our presentation, we distinguish between the informal phase and the formal phase. The first of these is not enshrined in the Treaty and it concerns the conduct of discussions and the search for amicable solutions, by the European Commission and a Member State, in order to avoid the initiation of this procedure. Specifically, through a letter, the Commission requests certain clarifications from the Member State concerned on the issues with which it has been notified or it has noticed as a result of its own investigations. The Commission thus identifies infringement cases, which may relate to: an infringement of European Union law (which are either nontransposition of a directive within the express term, improper transposition of a directive or incorrect application of EU law); a failure to notify national measures taken and applied. In the latter situation, the obligation of Member States to ensure the notification, in the database managed by the General Secretariat of the European Commission, of all significant normative acts is violated. In this respect, in Case C-543/17, European Commission v. The Kingdom of Belgium (Judgement of the Court, Grand Chamber, 2019), the Court of Justice established the obligation of Member States to provide sufficiently clear and precise information on national transposition rules, indicating for each provision of a directive, the appropriate national transposition rule. Thus, the Commission considers that the correlation table is the most efficient way to determine the conformity between the internal provisions and those of the transposed directive (Decision no. 561/2009, art.17 para.(2) lit. c), art.20 para. (6), art.45 and Annex 3, Government).

The procedure begins as a result of the Commission's own investigations or of complaints from citizens, businesses or other stakeholders, as well as due to the failure to communicate the transposition of a directive by a Member State. For better processing the complaints of citizens, the Commission provides a standard form for such an application, to be filled online, according to specific requirements (European Commission, 2017).

Therefore, in the informal phase, the first step is the submission of a complaint to the European Commission (2021) or its self-notification, following the investigations undertaken. Then, there are two different moments: recording and analyzing the case of infringement. After a careful examination of all existing facts and laws, the Commission will either close the case or send a letter of notification.

The formal phase has two distinct important stages: the pre-litigation stage and the litigation stage. The first one starts when a letter of formal notice is sent to the Member State concerning the violation found. This letter, which is of a legal nature, usually contains a single case of infringement, but it may be accompanied by an 
annex, which includes other infringements of the European Union law. The purpose of this document is to give the Member State concerned the opportunity to present its views on the issue identified. The Member State's observations are the response to this letter and must be provided within 2 months. This is followed by a reasoned opinion, issued by the Commission within 3 months of receipt of the Member State's explanations or its lack of reaction. That opinion is a detailed statement, showing the reasons that led the Commission to find a violation of the legal system of the European Union. It is followed by the Member State's reply, which must be sent within 2 months of receipt of the Commission's formal position, and which must present detailed measures that will be taken by that State. The above period may be extended by the Commission, due to special circumstances. The request for an extension of this deadline for compliance with the position of the EU executive must contain a precise program of the stages of a legislative procedure, which would result in the adoption of a normative legal act in compliance with the Union's law. The additional time granted may not exceed three months. The last important moment of the pre-litigation stage is the Commission's decision to refer the matter to the Court of Justice, which must be completed within a maximum period of 12 months after the initiation of the infringement procedure.

The litigation stage begins with the referral to the Court of Justice by the Commission, made within a month from the date of this decision. The settlement of the case ensues next. Thus, the European Court determines whether there is a noncompliance with the European Union law in the dispute submitted. If so, it orders the administration of proofs and conducts the trial. At the end of the latter, the General Advocate, which defends general interests in an independent and neutral manner, presents his claims, which the Court takes into account in its judgment, to a large extent, although it is not obliged to do so. However, the Court in Luxembourg is not competent to state the measures to be taken by the State concerned.

An important moment in this phase is the implementation of the judgment of the Court. Thus, the Member State concerned has three months to take the necessary measures and to forward them to the Commission. If the State does not comply, the Commission shall send the Member State a second letter of formal notice, stating its obligation to take the appropriate measures. In the absence of the latter, after the expiry of three months, the European Executive shall issue a reasoned opinion and indicate the points at which the State failed to comply with the judgment. If the Member State does not take adequate action in this case either, the Commission will bring it before the Court for a second time. The Commission may request the Court to order the state concerned to pay a lump sum and/or a penalty payment. The first time when these two sanctions were combined was the 2005 judgment of the Court of Justice of the Commission v. France case, for the same infringement of European Union law (Judgement of the Court, Grand Chamber, 2005). For reasons of transparency, the Commission publishes the criteria it intends to apply to the Court to indicate the appropriate financial penalties in the circumstances of each case and the method of their calculation (European Commission, 2021).These criteria refer to: the seriousness of the infringement (taking into account the importance of the 
infringed EU rules and the impact of the infringement on the general and particular interests), duration/period of the violation, the state's ability to pay, ensuring that the deterrent effect of the sanction can avoid recidivism. In assessing the importance of the infringed EU provisions, the Commission will take into account their nature and extent rather than their rank in the hierarchy of European Union sources of law. For example, the breaches of fundamental rights under the Treaty currently in force must be considered serious. The effects of the violation on the general or particular interests can refer to: the loss of own resources for the community, serious or irreparable damage to human health or the environment, economic or other damages suffered by individuals and economic operators, the volume of the population affected by the violation. For Romania, the amount of penalties that the Commission may propose is the following: minimum lump sum of EUR 1.723 million; penalties from EUR 2.082 andEUR 124.900 per day of delay after the judgment has been delivered (European Commission, 2020a). As coordinator of European affairs, the Ministry of Foreign Affairs draws up the annual transposition plans and submits its to the Government for approval.

It is interesting to note that, in the period 2014-2016, over $80 \%$ of the number of complaints filed against Member States were closed and in 2017-2019 over $95 \%$ of complaints were rejected for various reasons - the absence of a violation of EU law, errors in the elaboration of the requests or their withdrawal.

For a better implementation of the EU law, in 2019, the Commission elaborated guidelines in common agricultural policy, employment and social affairs, transparency on contract terms, energy and environment.

In its Report from July 2020, The European Commission reported that in 2019, it initiated 797 infringement cases for all Member States (a number that increased significantly, compared to only 644 new cases in 2018), most of which in areas such as: environment (175), internal market, industry, entrepreneurship and SMEs (147), mobility and transport (83). In the same period, 1564 infringement procedures remained to be resolved (European Comission, 2020b). Of the total new cases reported in 2019, most were concerned with the late transposition of EU's directives.

In 2020, 785 new procedures were launched in this area. One notices that more than $70 \%$ of Member States have an increased level of being targeted by this procedure, while only seven have managed to reduce their level. This indicates a serious problem with their attitude of compliance with the EU law as a whole, whether it is a breach of the legal order of the Union or a non-transposition or late or inadequate transposition of directives.

In 2021, the Commission initiated a total of 1821 cases for EU Member States, most of which referred to countries such as Spain, Greece, Belgium, Poland, Bulgaria, Italy, Germany, Romania. The only country that obviously stands out in terms of the small number of open infringement cases is Denmark (29 cases) and it is followed by Lithuania, Estonia, Finland and the Netherlands. 


\section{Infringement procedure in Romania}

Over $90 \%$ of the infringement cases initiated against Romania in the period 2009-2014 were in the field of environment.

In the period 2015-2019, Romania registered a small yearly increase of new procedures for violation of specific obligations. Existing cases of late transposition of EU law as well as new cases increased between 2015 and 2016; after that, they decreased steadily until 2019, when most were reported in the fields of environment, mobility and transport.

In 2019, the European Commission opened 38 specific infringement proceedings (new infringement cases opened) and 17 new late transposition infringement cases against the Romanian state. They referred, in particular, to: environment, taxations and customs union, internal market, industry, entrepreneurship and SMEs, mobility and transport.

In 2020, another 44 cases were initiated, most of them in the fields of environment (15), energy (9), mobility (7), justice, fundamental rights and citizenship (4). The Court has been notified on two cases concerning air quality and non-transposition of a directive regarding landfills. In one case concerning the nontransposition of an anti-money laundering directive (Directive (EU) 2015/849), the Commission suggested to the Court the application of Article 260 (3).

In 2021, 80 procedures were launched against Romania, most of which were registered in the fields of environment, energy, financial stability, financial services and capital markets union, mobility and transport, home affairs. It is significant that most cases (53) are in the first stage of the procedure (letter of formal notice, according to Article 258 TFEU). In 21 other cases, the Commission issued a reasoned opinion. In a case on environmental issues, initiated in 2009, the litigation had begun in 2018 and after two years, Romania was sentenced to pay the costs by a judgment of the Court (Case C-638/18), Judgment of the Court of 30 April 2020, (European Commission v Romania, 2020c). In another case regarding environment, which started in 2012, the European executive sent a letter of formal notice, for the implementation of the Court's decision, based on art. 260 TFEU. In a 2017 case, the Court sentenced Romania to pay a lump sum in the field of financial stability, financial services and capital markets union, for non-transposition of the aforementioned directive (the anti-money laundering directive). It should also be noted that, in over $50 \%$ of the cases mentioned above, the Romanian state did not send the Commission its point of view, which illustrates its tendency not to communicate in an effective and efficient way with the European executive, right from the beginning of this procedure, in order to remove any existing irregularities. Also, the large number of cases launched in 2021 highlights the delays registered by Romania regarding the obligation to comply with Union law.

Of the 11 infringement cases in which the Romanian state has been judged by the Court of Justice, in one case the Luxembourg court ruled in favor of Romania, in four cases in favor of the Commission while six proceedings were radiated, following the requests for withdrawal from the Commission. 
We further analyze some interesting aspects regarding a case of infringement directed against Romania and finalized with a decision of the Court.

In 2018, the Commission referred two cases to the Court, concerning Romania and Ireland, for failure to fulfill obligations, namely not having entirely transposed Directive 2015/849 within the deadline set in the reasoned opinions and not having communicated the appropriate national transposition measures. This directive aims to prevent the use of the EU financial system for the purpose of money laundering and terrorism financing. It had to be transposed by Member States into national law until June 26, 2016 and they were required to notify the appropriate measures taken in this respect.

The Commission also requested the Court to order Romania, on the one hand, to pay a daily penalty payment, starting from the judgment, for failure to fulfill its obligations to communicate the measures transposing the same directive and, on the other hand, to the payment of a lump sum.

In the case C 549/18, (European Comission, 2020d) the Court established that Romania's failure to fulfill its obligations concerns the scope of Article 260 (3) of the Treaty on the Functioning of the European Union. It found that the European executive had proved that Romania had not communicated the measures transposing Directive 2015/849 within the period laid down in the reasoned opinion. The Court emphasizes that the obligation to communicate transposition measures is the obligation of the Member States to provide sufficiently clear and precise information on national transposition rules, indicating in a directive for each provision the national transposition rule (Judgement of the Court, Grand Chamber, 2020).

The judgment states that the Commission is obliged to give reasons for the nature and amount of the financial penalty requested, in the light of the guidelines which it has drawn up, since the court must comply exactly with the Commission's proposals. The sanction proposed by the Commission must be adapted to the circumstances and be proportionate to the infringement committed (European Comission, n.d.). It depends on the gravity of the violation, its duration, and the state's ability to pay. Thus, in the case presented above, the Court ordered Romania to pay the Commission a lump sum of EUR 3,000,000.

\section{Conclusions}

The Commission's supervisory work on compliance of the national legal systems with EU's law is proving to be effective, since most infringement cases are launched at its own initiative.

For the best execution of the EU law, the Commission has established various modalities, such as: guidance documents, imposition of plans, expert groups, explaining documentsand providing trainings.

The most important observation that can be made after analyzing the data provided in the Commission's annual reports is that the objective of the infringement procedure, which is to persuade Member States to comply with EU'slaw, has been achieved by substantially reducing the number of cases inthe pre-litigation stage. 
From January 1, 2007, a total of 1514 infringement proceedings were initiated against Romania, outof which $92 \%$ are closed cases. The other 120 active infringement cases concernthe incompatibility of national legal rules with EU's law or cases of incorrect application of EU's law (74) and the failure to comply with the obligation to notify national measures transposing Union directives (46) (European Commission, Infringement decisions, Romania).

Over $66 \%$ of the cases pending are in the first stage of the pre-litigation phase, $20 \%$ in the second stage, which highlights the tendency of Romania not to be constantly concerned with the compliance of the national legal system with the EU's law.However, in 2020, positive changes had been made in this regardby the Ministry of Foreign Affairs, which elaborated the Annual Transposition Plan-2021, approved, then, by Memorandum no. K1/725/K2/1604, during the meeting of the Government of Romania on July 6, 2020. This document contains useful and detailed information on the transposition of the directives, with special attention to the urgent transposition of the remaining 17 directives for which infringement procedureshave been initiated (Memorandum K1/725/K2/1604, 2020).

Therefore, it is urgently necessary for Romania to put into practice, in a careful and constant manner, these well-systematized measures from the document mentioned above, in order to avoid the delays regarding the transposition of the directives.

In the same sense, for better results, Romania has the obligation to follow the examples of good practices of other EU's member states.

It is advisable to have a much more efficient cooperation between the Romanian government and the European Commission, because there is a sufficiently large number of cases triggered by the lack of notification of national measures on the transposition of directives.

The study of the data in the field clearly shows that Romania should make much more efforts to avoid the initiation of the infringement procedure right from its beginning, most cases of this kind being registered in the first phases of this mechanism.

Thus, all the EU's member states, and especially Romania must avoid, as much as possible, any violation of EU law in all fields in which the exercise of sovereignty has been ceded in favor of the Union's institutions. Thereby, we can deduce the very special international significance of the approached subject, because one of the most important requirements of the successful integration of a state in the European Union is the complete taking over of the Community acquis in the internal legislation of each member state.

\section{References}

European Commission. (2017). Formular de plângere privind încălcarea dreptului UE [Complaint form for breach of EU law]. European Commission. https://ec.europa.eu/assets/sg/report-a-breach/complaints_ro/

European Commission. (n.d). Infringement decisions. European Commission. https://ec.europa.eu/atwork/applying-eu-law/infringements- 
proceedings/infringement decisions/index.cfm?lang_code=EN\&typeOfSearch $=f$ alse\&active only $=1 \&$ noncom $=2 \& \mathrm{r}$ dossier $=\&$ decision date from $=\&$ decision da te to $=\& E M=$ RO\&title $=\&$ submit $=$ Search

European Commission. (2020a). Communication from the Commission. Updating of data used to calculate lump sum and penalty payments to be proposed by the Commission to the Court of Justice of the European Union in infringement proceedings. Official Journal of the European Union. https://eur-lex.europa.eu/legalcontent/EN/TXT/?uri=CELEX:52020XC0911(01)

European Commission. (2020b). Commission report and factsheets on monitoring the application of EU law. European Commission. https://ec.europa.eu/info/publications/2019commission-report-and-factsheets-monitoring-application-eu-law en

European Comission. (2020c). European Commission v Romania Case C 638/18.2020. Judgment of the Court.

https://curia.europa.eu/juris/document/document.jsf?text=\&docid=226008\&pag eIndex $=0 \&$ doclang $=$ RO\&mode $=1$ st $\&$ dir $=\& o c c=$ first $\&$ part $=1 \&$ cid $=2176517$

European Comission. (2020d). 16 July 2020. Case C-549/18. Judgement of the Court, Grand Chamber.

https://curia.europa.eu/juris/document/document.jsf?text=\&docid=228664\&pag

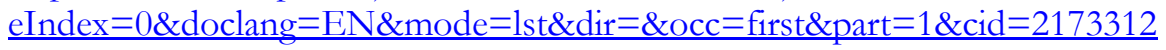

European Commission. (2021). Brussels Communication from the Commission. Adjustment of the calculation for lump sum and penalty payments proposed by the Commission in infringement proceedings before the Court of Justice of the European Union, following the withdrawal of the United Kingdom. European Commission.

https://ec.europa.eu/info/sites/default/files/communication_on_calculation_met hod 2021 en.pdf

Government of Romania. Hotărârea nr.561 din 10 mai 2009 pentru aprobarea

Regulamentului privind procedurile, la nivelul Guvernului, pentru elaborarea, avizarea şi prezentarea proiectelor de documente de politici publice, a proiectelor de acte normative, precum şi a altor documente, în vederea adoptării/ aprobării [Decision no. 561/2009 for the approval of the Regulation on procedures, at the Government level, for the elaboration, endorsement and presentation of draft public policy documents, draft normative acts, as well as other documents, for adoption/approval]. Monitorul Oficial, part 1, nr. 319 din 14 Mai, 2009 [Official Gazette, Part I, no. 319 of 14 May, 2009]. http://www.cdep.ro/pls/legis/legis pck.htp act?ida $=88407$

Judgement of the Court Grand Chamber. (2005). Case-304/02. 12 July 2005. Grand Chamber https://eurlex.europa.eu/legalcontent/EN/TXT/PDF/?uri=ecli:ECLI $\% 3 \mathrm{AEU} \%$ 3AC $\% 3 \mathrm{~A} 2005 \% 3 \mathrm{~A} 444$

Judgement of the Court Grand Chamber. (2019). Case C-543/17. European Commission v. the Kingdom of Belgium. Grand Chamber. https://eur-lex.europa.eu/legalcontent/EN/TXT/HTML/?uri=CELEX:62017CJ0543\&from=EN

Romanian Government. (2021). Memorandum. Romanian Government. https://mae.ro/sites/default/files/file/anul 2021/2021 pdf/memorandum guver n plan 2021r.pdf 